\title{
VOCATIONAL EDUCATION AND TRAINING COURSES: A TURNING POINT ON YOUNG ADULTS' ACADEMIC TRAJECTORIES ${ }^{1}$
}

\author{
Natália Alves ${ }^{1}$, Rita Queiroga ${ }^{1}$, Paula Guimarães ${ }^{1}$ António José Almeida ${ }^{2}$ \\ ${ }^{1}$ Institute of Education, University of Lisbon (PORTUGAL) \\ ${ }^{2}$ School of Business and Administration, Polytechnic Institute of Setubal (PORTUGAL)
}

\begin{abstract}
This paper is part of the research project YOUNG_ADULLLT (EU's Horizon 2020). The purpose of this project is to understand the interaction between lifelong learning policies, the conditions and life stages of young adults in situations of vulnerability, and the promotion of social development and inclusion in the European Union. It focuses on the analysis of life and educational paths of young adults who attend double certification VET Adult (EFA) courses in a public training center in the sub-region of Alentejo Litoral, in Portugal. The analysis developed is based on the Theory of the Life Course (Heinz et al., 2009; Walther, 2002, 2006). The adoption of this theoretical framework allows us to emphasize the agency and the role of the individual in the construction of one's own biography in interaction with the social context and the existing institutional arrangements. It also favors the understanding of the fragmentation and de-standardization of their life courses. This discussion is supported by an empirical corpus constructed on the basis of in-depth biographical interviews with young adults between 18 and 29 years old, attending double certification EFA courses, which have been object of a thematic content analysis (Bardin, 2009). The analysis of the data collected reveals biographies marked by geographic mobility and by events that constitute true turning points in their life paths: separation of the parents, death of one of them or teen pregnancy. From the school viewpoint, their trajectories are characterized by several school failures, dropouts and re-enterings and by a general feeling of disaffiliation towards regular school. Admission to double certification EFA courses occurs, for the majority of these young adults, after having experienced precarious and / or seasonal work experiences and poorly paid work. The achievement of a high school diploma is the main motivation for a return to formal education and to enroll in a training course, in order to have access to a better job in future, essential to have their own family and a stable life. In addition, to learn a profession corresponds in some cases to the fulfillment of a vocation, but in others it is no more than a non-choice. In the first case, the choice of the course is intentional and is at the service of a project where personal and professional development takes a prominent place. The strategies they develop are imbued with strategic rationality and reveal the ability to take advantage of the existing opportunity structures. In the second case, the profession for which they are being trained was the only one they had access to or the least worse choice, given their academic qualifications and the available training offer. The mismatch between the offered and the desired training provokes in the young adults a feeling of frustration with the present and of uncertainty about the future. However, in both situations, the life courses of these young adults are marked by destandardization and non-linearity aiming to fulfill the plan of a linear life course of education-job-housecar-family.
\end{abstract}

Keywords: Adult VET (EFA) double certification courses; Life Course; Young Adults

\section{INTRODUCTION}

Life course is commonly known as the sequence of life phases, mediated by institutions, such as school, work, training centre, community organizations, and such, with which a person interacts when living in a certain time and space. It describes the reciprocal relationships between processes at the individual and social levels and the aging phases [1]. Whereas Life course is a documented line of life, built of

\footnotetext{
1 Libro de Actas del 6th International Congress of Educational Sciences and Development / coord. por Tamara Ramiro Sánchez, María Teresa Ramiro Sánchez, María Paz Bermúdez Sánchez, 2018, ISBN 978-84-09-02091-1
} 
relationships with diverse institutions, following culturally defined patterns of gender and ethnicity, Biography is seen as the meaning-making made by one individual, when narrating its own life course.

Life course research sheds light to the influence of structural and institutional changes on human lives, since it brings solid investigations with elaborated theory and anchored in empirical work into that interplay between society and individuals over time [1]. A broad consensus has come across among research that individual agency in subjective biographies and structural factors in institutionalized life course interplay to result in educational success. Socio-economic and institutional factors of formal education structure educational trajectories, as individuals appropriate them in their biographical constructions [2]. Indeed, educational trajectories combine the education and life course perspectives, consisting of transitions and learning processes where biographical agency and institutional structure are interrelated [3].

Until a few decades, the life course of an individual was a linear sequence of school-work-familyretirement. During the midst of last century, the Fordist economic model strengthen the concept of a standardized life course. The childhood and youth phase consisted in a preparation for work structured in educational trajectories. Adulthood consisted in a phase at work and finally the old age would come after work [3].

Later research has given account of how transitions from youth to adulthood are undergoing destandardization. The process relates to factors like pluralization of lifestyles, larger periods in education, higher employment among females, flexible labour market and the actual trend to individualization. Reversibility, in opposition to linearity, determine transitions due to situations such as lost of a job or of a partner. In addition, because of extended time in school, transitions in other life areas such as lifestyle, housing, family or partnership no longer seem to be an automatic consequence of labour market entrance, showing different rhythms and logics. Also, youth transitions show fragmentation when youth like dependency situations goes along with adult autonomy. The category "young adult" arises when these young men and woman in their self-concept do not identify with neither "young" nor "adult" [4].

\section{METHODOLOGY}

The results described in this article are based on the Horizon 2020 EU research project named Policies Supporting Young People in their Life Course. A Comparative Perspective of Lifelong Learning and Inclusion in Education and Work in Europe (YOUNG_ADULLLT). It involved studying two functional regions [5] in Austria, Croatia, Bulgaria, Finland, Germany, Italy, Portugal, Scotland and Spain. It enquired on how lifelong learning (LLL) policies act at local contexts and within young adults' life course in creating opportunities of education and social inclusion, especially for those considered in vulnerable situations. Life Course Research helps to conceptualize the young adults as this is the target group of the LLL policies under study [6].

On a first moment, eighteen regions were identified following the concept of Functional Region (FR), such as a territorial unit not limited by geographical characteristics or historical happenings but as the result of the organization of economic and social connections, like labor markets for example[5]. On this basis, the project partners selected two 'contrasting cases' as FRs per country, considering socioeconomic indicators, labor markets and/or infrastructure. Particularly, the Institute of Education of the University of Lisbon chose Alentejo Litoral. This sub-region on one hand shows signs of a great economic dynamism and growth, due to the expansion of the Agriculture, Tourism and Industry sectors, and on the other hand data show youth long-term unemployment higher than the national and the EU27 average with a demographics undergoing a fast ageing process due to rural exodus and closing of basic services like post office, health center and schools.

In 2017, the 9 partners of the YOUNG ADULLLT research project conducted narrative biographical interviews to quite a number of young adults who benefited from a number of lifelong learning policies in the eighteen regions of the EU. These respondents were aged between 18 and 29 years old. Specifically, in Alentejo Litoral nine young adults were interviewed, three women and six men, who were enrolled in the adult vocational education and training courses, provided by the local unit of the Employment and Professional Training Institute (known in Portugal as, respectively, the EFA courses and the IEFP).

The data analysis followed a thematic content analysis [6] according to the following groupings of codes, agreed among all partners, still alowing adaptation to the collected data and local realities: Presentation 
of self, Construction of life story, Education and learning experiences, Life plan, concrete next steps and vocational project, Experience with the selected lifelong learning policy and Perception of his/ her own skills.

\section{RESULTS}

This section presents the description of the 9 young adults educational trajectories expressed in the interviews. In particular, distinguishing the actual trajectory from the rational supporting each one's choice of enrolling in a training course or re-entering formal education.

\subsection{Educational Trajectories}

The following table resumes de socio-demographic information on the nine interviewees. Subsequently, each educational trajectory and main motivation to enrol in a EFA course will be presented.

Table 1. Socio demographic data of the young adult interviewees'

\begin{tabular}{|c|c|c|c|}
\hline Code Name & Age & Gender & $\begin{array}{c}\text { Socio-economic } \\
\text { background }\end{array}$ \\
\hline Ana & 19 & $\mathrm{~F}$ & Working class \\
\hline João Miguel & 19 & $\mathrm{M}$ & Working class \\
\hline Maria & 18 & $\mathrm{~F}$ & Middle class \\
\hline José & 18 & $\mathrm{M}$ & Working class \\
\hline Hugo & 27 & $\mathrm{M}$ & Working class \\
\hline Rodrigo & 22 & $\mathrm{M}$ & Working class \\
\hline Júlio & 19 & $\mathrm{M}$ & Working class \\
\hline Adriano & 22 & $\mathrm{M}$ & Working class \\
\hline $\begin{array}{c}\text { Maria } \\
\text { Fernandes }\end{array}$ & 29 & $\mathrm{~F}$ & Working class \\
\hline
\end{tabular}

Ana describes herself as very calm. She lives with her mother and twin sister, near her mother's family. Since she started the $1^{\text {st }}$ grade, her parents moved often of place and so she attended four different schools until the $8^{\text {th }}$ grade, when her parents got separated. She particularly mentions the time period between the $5^{\text {th }}$ and the $8^{\text {th }}$ grade, corresponding to the longer time spent in a school. Ana's mother has the $11^{\text {st }}$ grade and works in a restaurant. Her father has the $4^{\text {th }}$ grade and is a truck driver.

Her educational trajectory is marked by her interest in drawing and nail fashion getting more of her attention than studying school subjects. She does not have any good or bad memories of her educational trajectory, presenting it as a routine without any major difficulties. Although for her moving school was hard when leaving the colleagues with whom she went along well.

She learned drawing by herself, not at school. The drawing passion came first then the nails fashion. She learned the nail painting technics with tutorials at the YouTube and doing her own and her friend's nails. Her parents always supported her.

She failed at the $8^{\text {th }}$ grade. Not because of a school move but due to learning difficulties and lack of inner motivation. She was more interested in drawing and nail fashion. This failure ended up with the initial idea of continuing to the upper regular secondary school to Arts course. She completed the $9^{\text {th }}$ grade and decided to drop-out school and get specialized training to fulfill her real interest and professional vocation.

At school I never learned such great things that has to do with the job. Usually you only learn about the subjects, you never learn anything connected to life outside. (...) We learn more, like. more talking to other people than the way we learn at school, at school it's more about writing. 
Private training not only is quite expensive but also demands the high school diploma, which she did not have. Then she found the Beautician course with double certification academic/professional in a public training center with the possibility of completing compulsory education $\left(12^{\text {th }}\right.$ grade).

I think I could have struggled to succeed every year and then have entered a course paid, but on the one hand, it was better like this, because I can take a course more in account, pay almost nothing and do, at the same time, the $12^{\text {th }}$.

Meantime waiting for that course to open, she enrolled in a Professional Course in the tourism sector, as not to be a NEET. She lives a very distance from the training center. She takes 3 buses to go to the training center and other 3 to come back, leaving at 6:30 in the morning, coming back 12 hours later. Nonetheless, she is very motivated, doing easily all modules and doing also some home study.

João Miguel is 19 years old, lives with his mother, who is hairdresser. His father works in the industry sector and sees him often. Both parents have the $4^{\text {th }}$ grade. His parents were interested in academic life and would like him to be above average and to study until the $12^{\text {th }}$ grade. Although if he passed the year it was enough. He first failed in the last year of primary school, as his mother and himself believed he was not ready to the $5^{\text {th }}$ grade, since he had 3 different teachers on that year. He describes felling unsecure to proceed.

He then failed 5 or 6 times, he cannot precise, at the $6^{\text {th }}$ grade due to lack of interest and attendance faults. He left school when he knew he was going to fail the 5th time, with 17 years old. The school psychologist informed him that he was near to the regular school age limit and to complete the compulsory school he had to go to elsewhere. He them decided to drop-out and go to work.

He attributes having failed so many times to having met new people with whom he started smoking, having gone on what he called „a low life“. He was only interested in one or two classes a day. He was more interested in skating and music. He believes his 1st flunk was a consequence of a tension between a teacher and his mother after a class situation with him and the teacher. After that, he was tired of always hearing the same thing and kept skipping classes and failing until dropping out.

He took over his educational path after having worked and as an alternative for not having found another job. Also a conversation with his old friend, to accomplish compulsory education school was decisive.

Maybe I heard advice from more different people, my family and my friends. A friend who had already gained that maturity and opened my eyes a little. (...) He said to take a good look at his life and to see their lives well and mine. Because we both went to school and he studied up to the 12 th grade. He did not get a job, but he already has his $12^{\text {th }}$, he has his life made, if he wants he can go to work. And I see myself here every time, every year that passes is another year, it's another year and it does not go more than this.

Once he registered in a public employment center as unemployed, he underwent a career guidance giving him the options of a professional school and the training center. For him, going to other cities was not an option, so he only had the training offer available.

He chose the wall painting course to accomplish the $6^{\text {th }}$ grade, as he had already experience with this activity, when he was called to paint the walls after being caught grafting them. The other option was gardening, but he was not able to see himself like a gardener. One the other hand, he was comfortable with the idea of becoming a wall painter. He waited one year to the course to start. He completed it in 6 months and after he stopped again for one summer. Then he chose the course he is attending at the moment, to accomplish the $9^{\text {th }}$ grade. This time he chose welding. Gardening was again the other option and he would not like to attend a course in another city. But now he regrets the choice. He doesn't like the subjects and he is fearing to work with the welding machines. He would like to choose an arts course or, even better, a culinary one. But none was available. has his preference.

Maria lives with her mother, who is a specialized kindergarten teacher and her stepfather, a businessman with the high school diploma. She did all school through, starting at the preschool, until the 3rd year, when she moved town. The adaptation to the new school was easy. She stayedin that school until the $6^{\text {th }}$ grade. Then she moved again from school on the 7th grade, and again the adaptation was very easy. She failed for the first time on the $8^{\text {th }}$ grade. She didn't want to know about school, undergoing a depression. The harder was making relationships in the new class, when repeating the $8^{\text {th }}$ grade.

Her mother has been present in during her educational trajectory but never insisted with her to study. Until $9^{\text {th }}$ grade she always had extra paid teachers to support her home study, as she was shy in classes. At dinner time, the family discusses the television news of the day. 
At the $10^{\text {th }}$ grade in the regular secondary school she chose the area of Humanities, as, in the regular school, the teachers only encourage students to choose between Sciences or Humanities. Vocational education was not an option:

But it is only if we go to Sciences or if we go to Humanities. There is nothing like that with the (VET) courses. They're just demotivating. They always said that the (VET) courses are like that for dumb people, right? So they do not support much students in going to the courses. (...) It's not the psychologists, it's the teachers themselves. They think that the smart ones go to Sciences, the more or less go to Humanities, and the others go to the (VET) courses. [laughs]

She would like to be a psychologist to help people as herself was helped at the $8^{\text {th }}$ grade, which would make her very proud of herself. But she did not like to study every day. She lost totally the interest so she failed and did not try again. She then started a professional course in tourism offered at the same school, because she would like to be an airplane stewardship, as she always liked that profession. The course was going well and she was having good marks, although she did not like the class mates, which somewhat influenced her choice of leaving this course. She dropped out when finding the actual course at a public training center, through a friend. She thought it had more to do with her interests like fashion, beauty and all that it is related. And since the course had already started, she felt she had to make a quick decision and grab that opportunity.

At this point the parents were disappointed as were expecting her to enter university and at the moment do not support her project of becoming a beautician, imagining that she will soon drop out.

They, first, did not like the idea very much, because they were a little bit shocked. [inaudible] that I want to leave school, because this (the training canter) is not quite a school. Afterwards, I am in the Beautician course, and they say that this course does not yield a lot of money, in the profession, and things like that. And that they always thought that ... they always idealized for me that I was going to university and take a course and all this, so this was not quite what they envisioned for me.

The adaptation to the training center was difficult and she almost dropped out, as she did not know anyone and people seem different from those of the bigger city, noticing the regional accent the colleagues had.

She also points the fact that the place is quite isolated, far from the city, and the long time she spends in the training center, having to wait 45 minutes to the bus to go home. This means not having time to spend with her friends outside the training center. Now, she found a boyfriend who became a reason to continue, when she was thinking to give up the course. Sometimes, the idea of dropping out comes back, as she is afraid of not earning enough money.

\section{CONCLUSIONS}

Alentejo Litoral presents one of the lowest levels of population density. Along side with a limited network and schedules of the public transport network, these conditions constitute great challenges to some of the biographies. Whether be it by long time spent in the bus, less time to meet friends or limited VET choice.

Events such as divorces have an impact in young adults' life course acting as true turning points where nothing will be as it was before.

The described school trajectories are marked by retention, by more or less prolonged school dropout and re-enterings, with a general feeling of disaffiliation towards regular school and lack of motivation to study academic subjects.

For those with working experiences, generally described as poorly paid, with hard working conditions and with no stable labour contract, the training course comes as an opportunity to get the upper secondary education diploma. Even though valuing the professional certification, the general aim is to get the academic certification with the perception that the completion of upper secondary education is an essential requirement for access to stable employment that allows for the transition to adulthood. To others, although they have not been confronted with the concrete situation, are aware of the difficulties that its absence causes, anticipating the effects of the generalization of compulsory schooling of 12 years and the requirements of the companies with regard to the level of schooling. 
As seen above, the biographies polarize between those choosing to accomplish the dream profession and those with no-choices. For some, it is the opportunity to realize a vocation (berufung) that in some cases is identified early in their life course and that in others emerges at the end or after the school path ended, as unsatisfactory professional experiences are occurring. In these cases, the choice of vocational education and training course is intentional and serves a defined professional project, where personal and professional fulfilment is highlighted. The strategies developed to materialize their professional project are provided with strategic rationality and reveal these young adults' ability to take advantage of the existing structure of opportunities.

For the others, learning a profession is a non-choice. Either because it was the only one available or the least bad choice, given their low academic qualifications. The mismatch between the desired profession and that offered by the skills formation system creates in young adults a sense of frustration about the present and uncertainty about the future. No one expresses the wish to practice the profession for which is being trained. The younger ones aspire to attend a new course that allows them the professional certification they want. The older ones, for whom the need for independence is more pressing, want a job whatsoever that assures them a salary that allows them to become independent and able for a family project.

All show fragmented and de-standardized life courses, as all go over the official time to be in school (18 years old), the dropout-reentering process show how transitions are reversible. In addition, some have reached the phases that in a linear life course come as a consequence of labor market entrance, such as partnership, family, lifestyle, car, and so on. On the other hand, we are facing situations of youth-like dependency, with those living with parents and similar, or when not, still supporting the expenses to allow the training experience.

\section{REFERENCES}

[1] A. Walther, "'Me, my education and I": constellations of decision-making in young people's educational trajectories," International Journal of Qualitative Studies in Education, vol. 28, no. 3, pp. 349-371, 2015.

[2] OECD, "REDEFINING TERRITORIES: FUNCTIONAL REGIONS," 24 Janeiro 2002. Retraived from

https://www.google.com/url?sa=t\&rct=j\&q=\&esrc=s\&source=web\&cd=1\&ved=0ahUKEwjomcaV4 OvaAhVCJJoKHYtdClkQFggoMAA\&url=http\%3A\%2F\%2Fwww.oecd.org\%2Fcfe\%2Fregionalpolicy\%2F15181241.doc\&usg=AOvVaw2E-ZW1rGaKhm_77j8OshsH. [Accessed 04 Maio 2018].

[3] L. Bardin, Análise de conteúdo, Lisboa: Edições 70, 2009.

[4] M. \&. W. A. Cuconato, "'Doing Transitions' in education," International Journal of Qualitative Studies in Education, vol. 28, no. 3, pp. 283-296, 2015.

[5] A. Walther, "Regimes of youth transitions. Choice, flexibility and security in young people's experiences across different European contexts," YOUNG Nordic Journal of Youth Rsearch, vol. 14, no.2, pp. 119-139, 2006.

[6] W. R. Heinz and J. \&. W. A. Huinink, The Life Course Reader. Individuals and Societies Across Time. Frankfurt/M. \& New York: Campus, 2009. 